Gut, 1972, 13, 278-284

\title{
Acetylator phenotype and adverse effects of sulphasalazine in healthy subjects
}

\author{
HASSE SCHRÖDER AND DAVID A. PRICE EVANS \\ From the Nuffield Unit of Medical Genetics, Department of Medicine, University of Liverpool
}

SUMMARY Sulphasalazine (salicyl-azo-sulphapyridine) was ingested by 27 healthy subjects for five days at a dosage of $4 \mathrm{~g}$ daily. The acetylator phenotype of each subject had been established previously. The serum concentrations of the parent drug and its sulphapyridine-metabolites were determined and the adverse effects were recorded. There was no correlation between the serum concentrations of sulphasalazine and the adverse effects. The slow acetylators obtained enhancement of serum concentrations of sulphapyridine earlier than the rapid acetylators. They also reported adverse effects earlier and of more pronounced nature than the rapid acetylators. The data as a whole suggest that the adverse effects observed were caused by the metabolite sulphapyridine and that they are influenced by the polymorphic acetylation.

Sulphasalazine (salicyl-azo-sulphapyridine) was first used in the treatment of ulcerative colitis by Svartz (1942). Controlled studies have demonstrated the clinical efficacy of the drug in mild and moderate cases of ulcerative colitis (Baron, Connell, LennardJones, and Avery Jones, 1962; Dick, Grayson, Carpenter, and Petrie, 1964). It has also been shown that the relapse rate is reduced upon sulphasalazine therapy (Misiewicz, Lennard-Jones, Connell, Baron, and Avery Jones, 1965). The use of the drug is, however, somewhat marred by adverse effects such as nausea, headache, abdominal discomfort, and malaise (Svartz, 1942; Lagercrantz, 1949; Morrison, 1952; Moertel and Bargen, 1959; Lennard-Jones, Longmore, and Avery Jones, 1960; Watkinson, 1961; Baron et al, 1962; Truelove, Watkinson, and Draper, 1962; Dick et al, 1964; Misiewicz et al, 1965). These effects usually begin after a few days on taking the drug but occasionally they appear after a fortnight (Bargen, 1962; Baron et al, 1962; Dick et al, 1964; Misiewicz et al, 1965). The symptoms seem to be related to the dose and can usually be reduced by temporarily reducing the dosage (Moertel and Bargen, 1959; Truelove et al, 1962; Baron et al, 1962). About 80 to $85 \%$ of the patients are, however, able to complete the treatment. Haematological reactions and rashes are rare.

It has been found that sulphasalazine ingested by humans is partially split at the azo linkage leading to the release of free sulphapyridine and 5-amino Received for publication 9 February 1972. salicylic acid (Svartz, Kallner, and Helander, 1945). This process probably occurs in the large intestine. A considerable proportion of sulphapyridine (as well as unsplit sulphasalazine) is absorbed whilst the 5 -amino salicylic acid moiety is largely excreted in faeces (Schröder and Campbell, 1972). Sulphapyridine, like sulphadimidine, isoniazid, and other drugs, is polymorphically acetylated in man (Schröder and Evans, 1972), some persons being genetically constituted as rapid acetylators (Mendelian dominants) and others as slow acetylators (recessives). Sulphapyridine is metabolized by both acetylation and hydroxylation. The products of the latter process appear in blood and urine conjugated to glucuronic acid. The current concept of the pharmacokinetics of sulphasalazine in man is summarized in Figure 1.

The aims of the present study were to see if the adverse effects of sulphasalazine were correlated with the serum concentrations of the parent drug or its metabolites or influenced by the polymorphic acetylation of sulphapyridine.

\section{Methods}

Twenty-seven healthy subjects (university medical school laboratory technicians, physicians, nurses, and final-year medical students) without a history of asthma, hay fever, eczema, adverse reactions to any drug, or gastrointestinal disorders participated in the experiment. Twelve of the subjects were female. The 


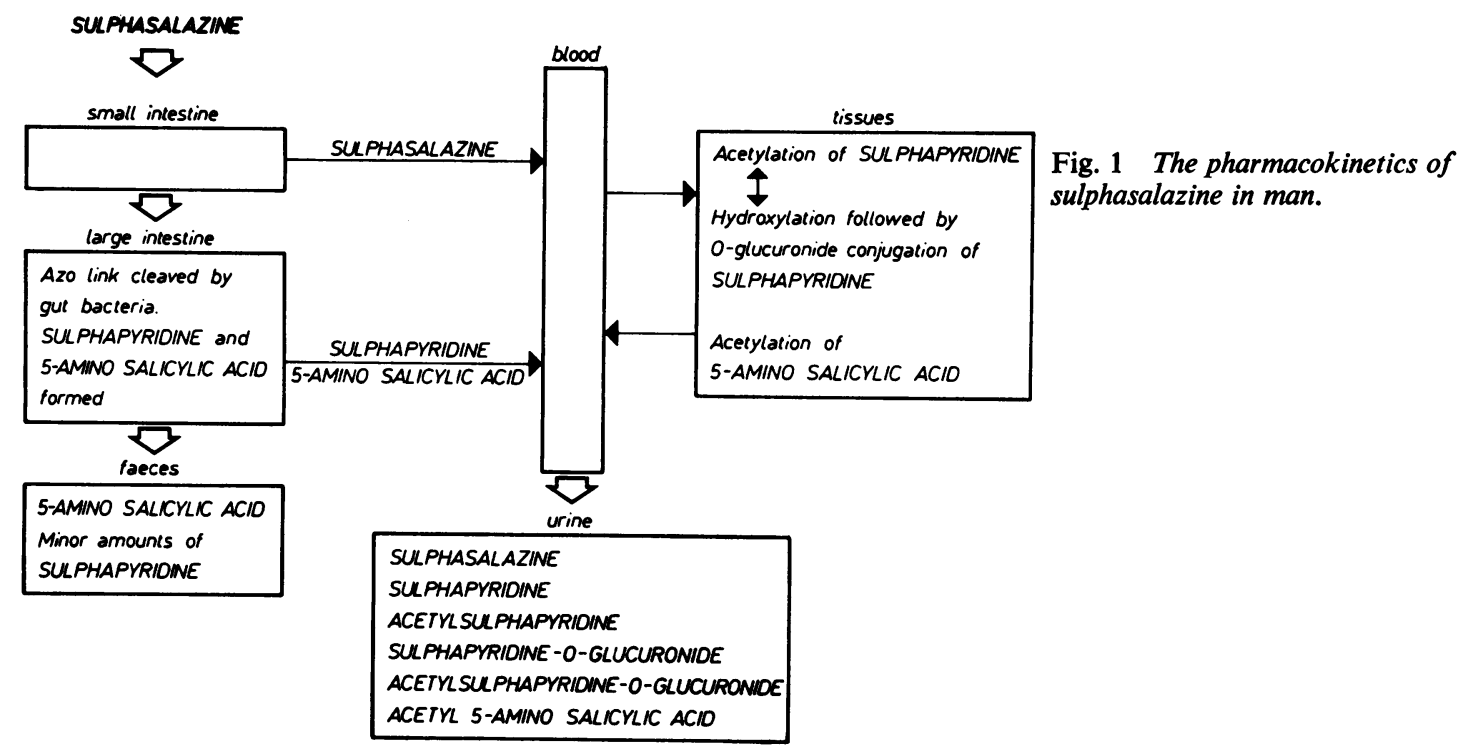

subjects were motivated to participate in the research in the sense that most had previously taken part in other experiments on drug metabolism and so were interested in the topic. With the exception of two slow acetylators, the subjects were not aware of their acetylator phenotypes. All volunteer subjects were paid and the sum paid was the same whether or not they completed the full 120 hours of the study. The first four subjects did not know about the adverse effects until they had actually experienced symptoms. Since most of the subjects worked in the same building and were able to discuss and compare their symptoms, it then became generally known that adverse effects occurred during this experiment.

The subjects were phenotyped as slow (15 subjects) or rapid (12 subjects) acetylators of sulphadimidine and sulphapyridine according to the procedure given by Evans (1969). Sulphasalazine was then administered as commercially available non-enteric coated tablets (Azulfidine, Pharmacia AB) in a dosage of $1 \mathrm{~g}$ four times a day for five days. A sample of blood was taken after 24 and 72 hours respectively before ingestion of the first dose of the day and after 120 hours. Adverse effects were voluntarily reported by subjects to the nurse superintending the study and collecting the specimens. When a symptom was volunteered the subjects were then further questioned for details but a full check list of possible symptoms was not employed.

The blood was allowed to coagulate at room temperature and the serum separated and then stored at $-20^{\circ} \mathrm{C}$. Starting on the morning of day 4 a 24-hour urine specimen was collected, the volume was measured, and an aliquot stored at $-20^{\circ} \mathrm{C}$.
The specimens were marked by random numbers and were analysed for sulphasalazine according to the procedure given by Sandberg and Hansson (1972) whilst sulphapyridine, acetyl sulphapyridine, sulphapyridine-O-glucuronide, and acetyl sulphapyridine-O-glucuronide were analysed by methods given by Hansson and Sandberg (1972). All determinations were performed in duplicate together with suitable blanks.

Two serum specimens were accidentally destroyed during transit and could not be analysed. They were taken after 24 and 120 hours and belonged to two male slow acetylators who completed the study.

Persons noting ratings of adverse effects and those making the chemical determinations were kept unaware of each others' results until all the determinations were finished.

An analysis of variance, two-way layout, was performed using a computer program BMD 05V (Dixon, 1965).

\section{Results}

\section{PHARMACOKINETICS}

There was a pronounced interindividual variation in serum concentrations of sulphasalazine (Fig. 2a). In order to find out if and when steady state serum concentrations of sulphasalazine were obtained, a comparison was made between the values obtained after 24, 72, and 120 hours for each subject. There were no significant differences in serum concentrations of sulphasalazine between any of the 
a

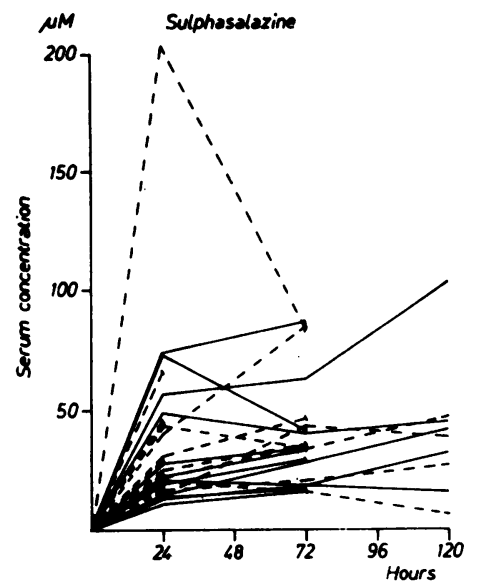

b

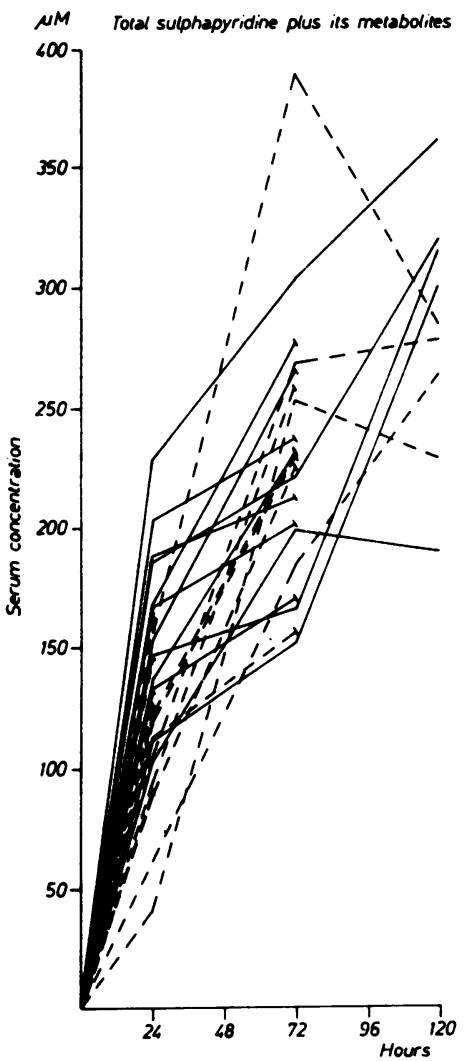

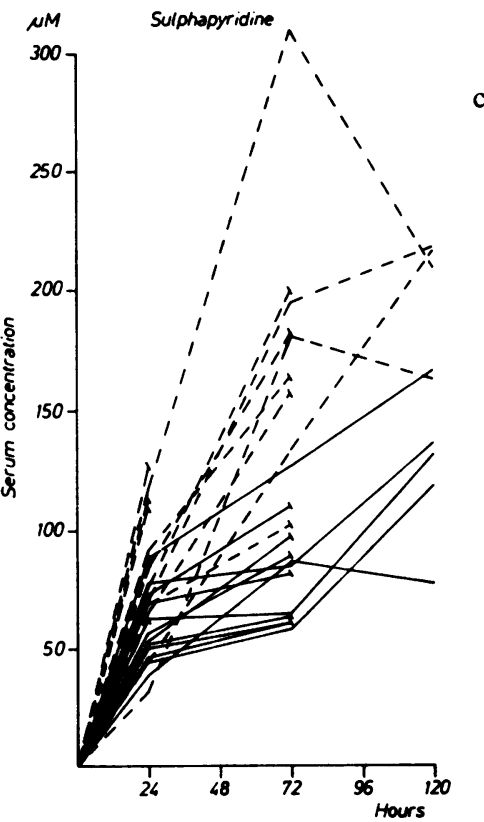
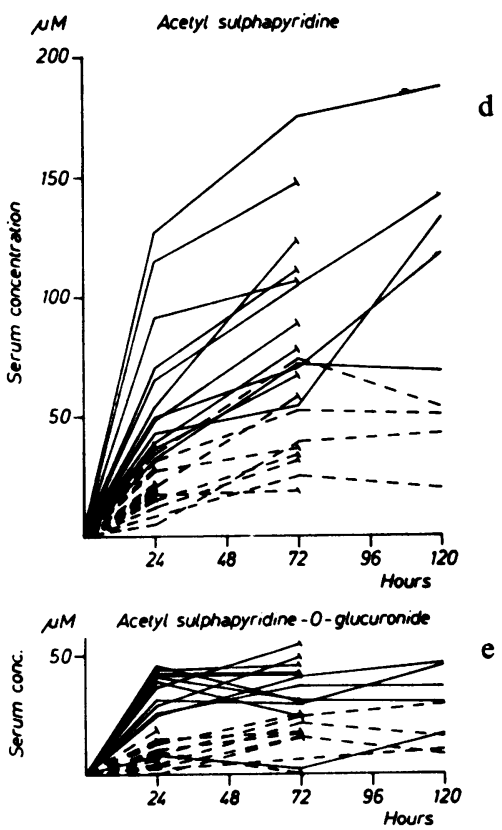

Fig. 2 Serum concentrations of sulphasalazine and of its sulphapyridine metabolites for 27 healthy subjects for as long as they remained on $4 \mathrm{~g}$ sulphasalazine daily. Slow acetylators of sulphapyridine $(n=15):--;$ rapid acetylators of sulphapyridine $(n=12)$;

Two specimens taken after 24 and 120 hours were destroyed before analysis. They belonged to slow acetylators who completed the study. 
days suggesting that steady state was obtained already after 24 hours.

The serum concentrations of sulphasalazine were transformed into $\log _{10}$ form in order to normalize the distribution of this quantity. A two-way analysis of variance (components of variation were acetylator phenotype and sex) applied to the data obtained after 24 and 72 hours revealed that there were no significant differences in serum concentrations of sulphasalazine between slow and rapid acetylators of sulphapyridine (Table I) or between sexes. There was a significant regression of serum sulphasalazine concentration on body weight and on height, but the subjects who discontinued the experiment did not differ as regards their mean weight or mean height from those who completed.

The serum concentrations of total sulphapyridine, ie, sulphapyridine plus its metabolites, showed a lesser extent of interindividual variation than those of sulphasalazine (Fig. 2b). Attainment of steady state serum concentrations of total sulphapyridine was tested as for sulphasalazine. It was found that the values obtained after 72 and 120 hours were both significantly higher than those after 24 hours $(\mathrm{P}<$ 0.0005 ). However, the difference between the values obtained after 72 and 120 hours was not significant, suggesting steady state serum concentrations of total sulphapyridine to be obtained by 72 to 120 hours. The two-way analysis of variance showed that there were no significant differences in serum concentrations of total sulphapyridine between sexes (Table I).

The acetylator phenotype had a significant influence upon the serum concentrations in that the slow acetylators had more of sulphapyridine and less of acetyl sulphapyridine and acetyl sulphapyridineO-glucuronide than the rapid acetylators (Fig. 2c-e and Table I). The slow acetylators had a significantly lower percentage of glucuronidized sulphapyridine in serum than the rapid acetylators (Table I). No difference between sexes in serum concentrations of any metabolite was found. The slow and rapid acetylators did not differ significantly from each other in their mean age, body weight, or height.

Urine was obtained from 16 subjects (seven slow and nine rapid acetylators). The total urinary excretions of sulphasalazine and its sulphapyridine metabolites were lower in the slow than in the rapid acetylators but the difference failed to attain statistical significance (Table II). The acetylator phenotypes differed in the urinary excretion of the various sulphapyridine metabolites in that the slow

\begin{tabular}{|c|c|c|c|c|c|c|}
\hline \multirow[t]{3}{*}{ Metabolite } & \multirow[t]{3}{*}{ Hours } & \multicolumn{4}{|c|}{ Mean Serum Concentrations $(\mu \mathrm{g} / \mathrm{ml})$} & \multirow{3}{*}{$\begin{array}{l}\text { Analysis of Variance } \\
\text { Probability values } \\
\text { Derived from F Test } \\
\text { Difference } \\
\text { Slow-Rapid }\end{array}$} \\
\hline & & \multicolumn{2}{|l|}{ Male } & \multicolumn{2}{|c|}{ Female } & \\
\hline & & Slow ${ }^{2}$ & Rapid $^{3}$ & Slow & Rapid $^{5}$ & \\
\hline Sulphasalazine & $\begin{array}{l}24 \\
72\end{array}$ & $\begin{array}{r}9 \cdot 2 \\
11 \cdot 1\end{array}$ & $\begin{array}{r}9 \cdot 6 \\
10 \cdot 1\end{array}$ & $\begin{array}{l}17 \cdot 6 \\
16 \cdot 7\end{array}$ & $12 \cdot 6$ & $\begin{array}{l}\text { NS } \\
\text { NS }\end{array}$ \\
\hline Sulphapyridine? & $\begin{array}{l}24 \\
72\end{array}$ & $\begin{array}{l}16 \cdot 5 \\
30 \cdot 7\end{array}$ & $\begin{array}{l}11 \cdot 3 \\
15 \cdot 6\end{array}$ & $\begin{array}{l}17 \cdot 5 \\
40 \cdot 6\end{array}$ & $\begin{array}{l}13 \cdot 1 \\
18 \cdot 1\end{array}$ & $\begin{array}{l}<0.025 \\
<0.0005\end{array}$ \\
\hline Acetyl sulphapyridine ${ }^{7}$ & $\begin{array}{l}24 \\
72\end{array}$ & $\begin{array}{l}4 \cdot 6 \\
7 \cdot 7\end{array}$ & $\begin{array}{l}10 \cdot 5 \\
17 \cdot 5\end{array}$ & $\begin{array}{l}4 \cdot 2 \\
8 \cdot 6\end{array}$ & $\begin{array}{l}17 \cdot 5 \\
25 \cdot 1\end{array}$ & $\begin{array}{l}<0.0005 \\
<0.0005\end{array}$ \\
\hline Sulphapyridine-O-glucuronide ${ }^{7}$ & $\begin{array}{l}24 \\
72\end{array}$ & $\begin{array}{l}1 \cdot 0 \\
0.8\end{array}$ & $\begin{array}{l}0.6 \\
0.3\end{array}$ & $\begin{array}{l}0 \cdot 4 \\
1 \cdot 7\end{array}$ & $\begin{array}{l}0.2 \\
0.3\end{array}$ & $\begin{array}{l}\text { NS } \\
\text { NS }\end{array}$ \\
\hline Acetyl sulphaphyridine-O-glucuronide ${ }^{7}$ & $\begin{array}{l}24 \\
72\end{array}$ & $\begin{array}{l}1 \cdot 6 \\
4 \cdot 1\end{array}$ & $\begin{array}{l}7 \cdot 4 \\
7 \cdot 8\end{array}$ & $\begin{array}{l}1.8 \\
2.6\end{array}$ & $\begin{array}{l}5 \cdot 9 \\
5 \cdot 9\end{array}$ & $\begin{array}{l}<0.0005 \\
<0.005\end{array}$ \\
\hline Total sulphapyridine ${ }^{7}$ & $\begin{array}{l}24 \\
72\end{array}$ & $\begin{array}{l}23 \cdot 7 \\
43 \cdot 2\end{array}$ & $\begin{array}{l}29 \cdot 8 \\
41 \cdot 2\end{array}$ & $\begin{array}{l}23 \cdot 8 \\
53 \cdot 6\end{array}$ & $\begin{array}{l}36 \cdot 6 \\
49 \cdot 4\end{array}$ & $\begin{array}{l}<0.005 \\
\text { NS }\end{array}$ \\
\hline$\%$ Glucuronidized sulphapyridine ${ }^{7}$ & $\begin{array}{l}24 \\
72 \\
24 \\
72\end{array}$ & $\begin{array}{l}26 \cdot 1 \\
28 \cdot 0 \\
11 \cdot 4 \\
11 \cdot 5\end{array}$ & $\begin{array}{l}59 \cdot 6 \\
61 \cdot 2 \\
26 \cdot 8 \\
20 \cdot 0\end{array}$ & $\begin{array}{r}24 \cdot 9 \\
21 \cdot 1 \\
19 \cdot 3 \\
9 \cdot 0\end{array}$ & $\begin{array}{l}63 \cdot 4 \\
63 \cdot 4 \\
18 \cdot 7 \\
14 \cdot 0\end{array}$ & $\begin{array}{l}<0.0005 \\
<0.0005 \\
<0.0005 \\
<0.05\end{array}$ \\
\hline
\end{tabular}

Table I Two-way analysis of variance of serum concentrations of sulphasalazine and its sulphapyridine metabolites after ingestion of $4 \mathrm{~g}$ sulphasalazine daily

$\mathrm{NS}=$ not significant, $\mathrm{P}>0.05$

Degrees of freedom on day $1: 1,22$

Degrees of freedom on day 3: 1,17

'One spzcimen taken after 24 hours was destroyed before analysis. It belonged to a slow male. There were no significant differences between sexes, nor were there any interactions between acetylator phenotype and sex. One specimen taken after 24 hours was destroyed before analysis. It belonged to a slow male.

${ }^{2} \mathrm{n}=6$ on Day $1, \mathrm{n}=4$ on Day 3.

$\mathrm{s}_{\mathrm{n}}=8$ on Day 1 and 3 .

$4 \mathrm{n}=8$ on Day $1, \mathrm{n}=5$ on Day 3.

$s_{n}=4$ on Days 1 and 3.

'Differences were not significant even after transformation into $\log _{10}$ scale.

'Calculated as sulphapyridine. 


\begin{tabular}{|c|c|c|c|c|}
\hline \multirow[t]{2}{*}{ Metabolite } & \multicolumn{4}{|c|}{ Urinary Excretion (mean $\pm 95 \%$ confidence limits assuming $t$ distribution) } \\
\hline & $\begin{array}{l}\text { Acetylator Phenotype } \\
\text { Slow }(n=7)\end{array}$ & Rapid $(n=9)$ & $t^{2}$ & $\boldsymbol{P}^{\mathbf{2}}$ \\
\hline $\begin{array}{l}\text { Sulphasalazine } \\
\text { Sulphapyridine }^{8} \\
\text { Acetyl sulphapyridine } \\
\text { Sulphapyridine-O-glucuronide } \\
\text { Acetyl sulphapyridine-O-glucuronide } \\
\text { Total excretion } \\
\text { Proportion acetylated sulphapyridines } \\
\text { Proportion glucuronidised sulphapyridine }\end{array}$ & $\begin{array}{l}5 \cdot 7 \pm 2 \cdot 4 \\
26 \cdot 9 \pm 5 \cdot 7 \\
23 \cdot 8 \pm 6 \cdot 6 \\
24 \cdot 8 \pm 3 \cdot 0 \\
18 \cdot 8 \pm 7 \cdot 3 \\
58 \cdot 4 \pm 13 \cdot 1 \\
45 \cdot 3 \pm 5 \cdot 9 \\
46 \cdot 3 \pm 9 \cdot 4\end{array}$ & $\begin{array}{l}4.8 \pm 1.5 \\
9.7 \pm 2.0 \\
42.4 \pm 7.9 \\
10.7 \pm 1.5 \\
32.4 \pm 8.9 \\
72.6 \pm 14.7 \\
78.6 \pm 2.7 \\
45.3 \pm 9.9\end{array}$ & $\begin{array}{r}0 \cdot 80 \\
7 \cdot 61 \\
4 \cdot 09 \\
10 \cdot 73 \\
2 \cdot 67 \\
1 \cdot 64 \\
12 \cdot 18 \\
0 \cdot 17\end{array}$ & $\begin{array}{l}\text { NS } \\
<0.0005 \\
<0.005 \\
<0.0005 \\
<0.02 \\
\text { NS } \\
<0.0005 \\
\text { NS }\end{array}$ \\
\hline
\end{tabular}

Table II Urinary excretion of sulphasalazine and its sulphapyridine metabolites ${ }^{1}$

${ }^{1}$ Urine was collected for 24 hours during day 4 after ingestion of $4 \mathrm{~g}$ sulphasalazine daily. Corrections have been made for differences in molecular weights.

2Differences between slow and rapid acetylators were tested by Student's $t$ test. NS $=$ Not significant, $P>0.05$.

'Calculated as \% of total excretion.

Calculated as \% of the dose.

'Calculated as \% of total recovery of sulphapyridine.

acetylators excreted a higher proportion as sulphapyridine and sulphapyridine-O-glucuronide and a lower proportion as each of the two acetylated metabolites than the rapid acetylators. These differences between slow and rapid acetylators were significant (Table II). However, the proportion in urine of sulphasalazine and of sulphapyridine that was glucuronidized was not significantly different for the two acetylator phenotypes (Table II).

\section{ADVERSE EFFECTS}

Of the 15 slow and 12 rapid acetylators participating in the study, 14 slow and 10 rapid acetylators reported at least one adverse effect and 10 slow and seven rapid acetylators (in all $63 \%$ ) discontinued taking the tablets before the end of the experiment because of the severity of the symptoms. Figure 3 shows that of the slow acetylators, one discontinued after day 1, five after day 2, and two after each of days 3 and 4. Of the rapid acetylators, three discontinued the experiment after day 3 and four after day 4. Neither of the sexes was represented more significantly among those who discontinued before the end of the study (tested by $\chi^{2}$ with Yates' correction).

Serum concentrations of sulphasalazine, sulphapyridine, and metabolites after 24 hours' therapy in subjects who discontinued before 72 hours were compared (separately in the two acetylator phenotypes) with 24-hour values in subjects who continued the experiment to give blood specimens after $\mathbf{7 2}$ hours. No significant differences were found. Similarly, no significant differences in serum concentrations were found after 72 hours between subjects who discontinued before 120 hours and those who completed the study (Fig. 2a-e). Neither of the acetylator phenotypes was significantly more represented among those who discontinued before the end of the study (tested by $\chi^{2}$ with Yates' correction).

Among those who discontinued before the end of the study, the slow acetylators consumed $22.2 \pm 5.6$ tablets (mean $\pm 95 \%$ confidence limits assuming

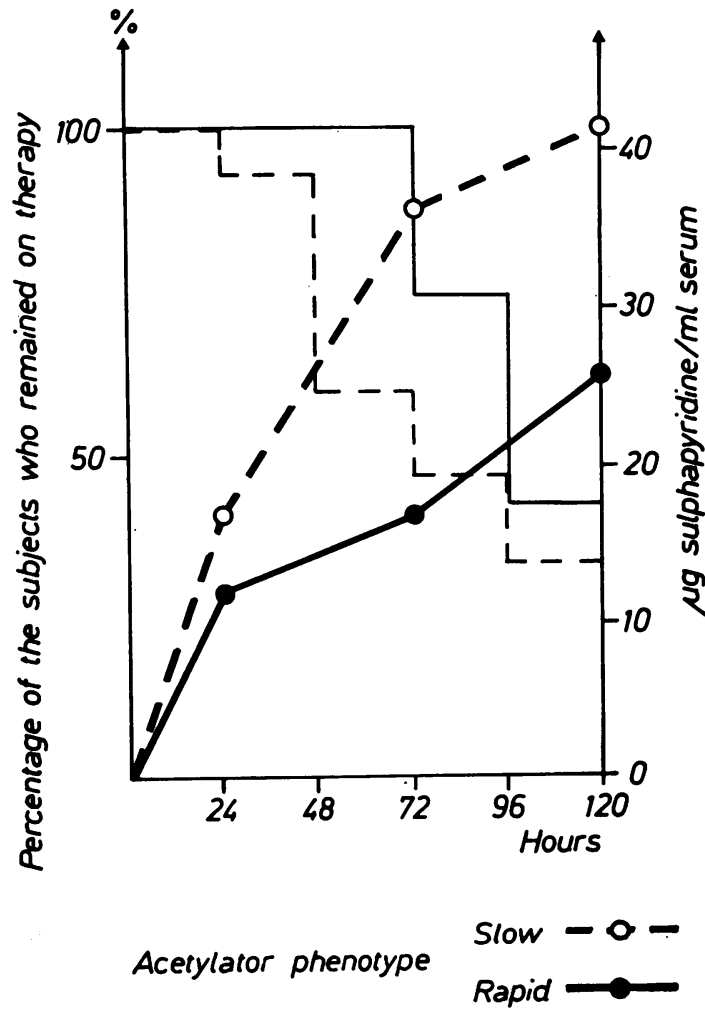

Fig. 3 Percentage of slow $(n=15)$ and rapid $(n=12)$ acetylators of sulphapyridine who remained on a full daily dose of $4 \mathrm{~g}$ sulphasalazine for five days. The mean serum concentrations of the metabolite sulphapyridine are also shown. 


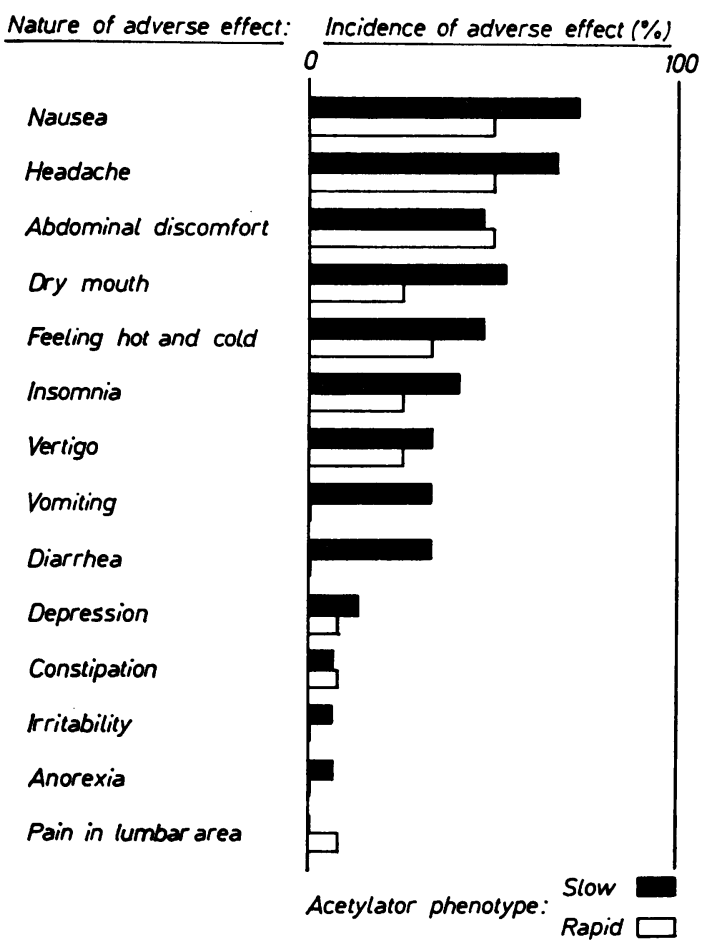

Fig. 4 Nature and incidence of adverse effects reported by 27 healthy subjects (15 slow and 12 rapid acetylators of sulphapyridine) for as long as they ingested $4 \mathrm{~g}$ sulphasalazine daily for five days.

$\mathrm{t}$ distribution) and the rapid acetylators $30.9 \pm 4.5$ tablets (mean $\pm 95 \%$ confidence limits assuming $t$ distribution). This difference between slow and rapid acetylators is significant $(P=0.02)$.

During the investigation, 14 different adverse symptoms were recorded. Figure 4 gives their nature and incidence for slow and rapid acetylators. Most frequent were nausea, headache, and abdominal discomfort. The slow acetylators had a higher incidence than the rapid acetylators of 11 of the symptoms and the same incidence of two symptoms. Five (33\%) of the slow acetylators vomited and the same number of them had diarrhoea but none of the rapid acetylators reported any of these symptoms. The number of adverse effects reported by each subject was higher for the slow acetylators than for the rapid acetylators (Table III), and when considering only those who discontinued before the end of the study, the difference between the acetylator phenotypes was significant, $P=0.035$ (Table III). There was a distinct impression that the adverse effects were worse when physical exertion was greater. The one subject who reported pain in the lumbar area had a very low intake of liquids.

\section{Discussion}

Our results show that the adverse effects experienced by subjects ingesting sulphasalazine were correlated with the acetylator phenotype in that slow acetylators of sulphapyridine developed a greater number of symptoms which appeared earlier than in the rapid acetylators.

In this study nausea, headache, and abdominal discomfort were the most frequent symptoms reported by the subjects and they are common symptoms registered for patients on sulphasalazine therapy (Svartz, 1942; Lagercrantz, 1949; Morrison, 1952; Moertel and Bargen, 1959; Lennard-Jones et al, 1960; Watkinson, 1961; Baron et al, 1962; Truelove et al, 1962; Dick et al, 1964; Misiewicz et al, 1965; Collins, 1968). Nausea and headache are common symptoms also for patients on sulphapyridine therapy (Hawking and Lawrence, 1950).

About $63 \%$ of the subjects stopped the experiment because of side effects and this high incidence is a relatively undesirable aspect of the study.

The higher incidence of adverse effects found by us compared with experiences in the therapeutic use of sulphasalazine may be due to a combination of factors. It is well known that subjects on treatment even with placebo will report subjective adverse

\begin{tabular}{|c|c|c|c|c|c|}
\hline & \multirow{2}{*}{$\begin{array}{l}\text { Acetylator } \\
\text { Phenotype }\end{array}$} & \multicolumn{4}{|c|}{ Number of Adverse Effects Reported by Each Subject } \\
\hline & & $n$ & $\begin{array}{l}\text { Mean } \pm 95 \% \text { Confidence Limits } \\
\text { Assuming } t \text { Distribution }\end{array}$ & $t^{2}$ & $P^{\mathbf{1}}$ \\
\hline $\begin{array}{l}\text { All subjects who reported any adverse } \\
\text { effect } \\
\text { Subjects who reported severe adverse effects } \\
\text { and discontinued drug ingestion before the end } \\
\text { of day } 5\end{array}$ & $\begin{array}{l}\text { Slow } \\
\text { Rapid } \\
\text { Slow } \\
\text { Rapid }\end{array}$ & $\begin{array}{r}14 \\
10 \\
10 \\
7\end{array}$ & $\begin{array}{l}4.9 \pm 1 \cdot 3 \\
3.4 \pm 1 \cdot 3 \\
5 \cdot 8 \pm 1 \cdot 3 \\
3.6 \pm 1.9\end{array}$ & $\begin{array}{l}1.74 \\
2.32\end{array}$ & $\begin{array}{l}\text { NS } \\
0.035\end{array}$ \\
\hline Subjects who completed the study & $\begin{array}{l}\text { Slow } \\
\text { Rapid }\end{array}$ & $\begin{array}{l}5 \\
5\end{array}$ & $\begin{array}{l}2 \cdot 2 \pm 2 \cdot 7 \\
1 \cdot 8 \pm 2 \cdot 2\end{array}$ & $0 \cdot 32$ & NS \\
\hline
\end{tabular}

Table III Number of adverse effects for subjects ingesting $4 \mathrm{~g}$ sulphasalazine daily for five days

${ }^{1}$ Differences between slow and rapid acetylators were tested by Student's $t$ test. NS $=$ Not significant. $P>0 \cdot 05$. 
effects. Since in this study many subjects had some forewarning of the possible occurrence of adverse effects, perhaps 'placebo effects' may have been magnified. The fact that most of the subjects worked in the same building allowed the subjects to compare their impressions of the pharmacokinetic study in which they were participating. If a colleague suffered from severe adverse effects, a subject might overestimate his own pain and thus stop participating in the study. There is. however, no reason to suppose that the two acetylator phenotypes differ in their reactions to placebo or to gossip in the surroundings. The participants were healthy subjects performing their normal work in the laboratories and in the ward. Any impairment of their ability to perform normal duties would be recognized and decrease their desire to continue the experiment. Patients suffering from ulcerative colitis are, however, very willing to withstand some degree of adverse effects without complaint because of the prospect of benefit from sulphasalazine therapy. There may be differences in the metabolism of sulphasalazine between healthy subjects and patients suffering from ulcerative colitis. The portion of sulphasalazine that is not absorbed along the small intestine enters the large intestine. We expect a patient suffering from ulcerative colitis to excrete this sulphasalazine in the stools before sulphapyridine is formed and absorbed, especially during the acute stage of the disease. This should give patients a slower increase in serum concentration of sulphapyridine than healthy subjects and they may thus more easily get accustomed to the drug. The impression that the adverse effects were worse when physical exertion was greater suggests that healthy subjects can have more severe symptoms than ulcerative colitis patients because they are more ambulant. During the studies reported by Evans (1969) many complaints of headaches and malaise were encountered in healthy working volunteers on high doses of sulphadimidine, but these were almost completely eliminated either by insisting on complete recumbency during the first two hours of the test or by reducing the dose. It must be emphasized that the metabolism of sulphasalazine may be different in normals and subjects with ulcerative colitis because of the disease processes. The conclusions reached in this study on normal subjects cannot, therefore, necessarily be applied to patients for whom the drug is used therapeutically.

There are no significant indications that higher serum concentrations of sulphasalazine increases the severity of the adverse effects. The present data as a whole indicate that the adverse effects that occur in subjects on sulphasalazine may be caused mainly by sulphapyridine and that the slow acetylators of sulphapyridine develop more symptoms which appear earlier than in rapid acetylators. Such a view would be in keeping with two previously published observations, viz, (1) that slow acetylators have a higher incidence of polyneuropathy on isoniazid treatment than rapid acetylators (Devadatta, Gangadharam, Andrews, Fox, Ramakrishnan, Selkon, and Velu, 1960), and (2) that in a double-blind investigation on phenelzine, Evans, Davison, and Pratt (1965) found that the severe adverse effects occurred only in slow acetylators.

We gratefully acknowledge the help of Miss M. F. Bullen and of Miss Lena Carlsson

\section{References}

Bargen, A. J. (1962). Ulcerative colitis. I. Medical management. Amer. Surg., 28, 630-635.

Baron, J. H., Connell, A. M., Lennard-Jones, J. E., and Jones, F. A. (1962). Sulphasalazine and salicylazosulphadimidine in ulcerative colitis. Lancet, 1, 1094-1096.

Collins, J. R. (1968). Adverse reactions to salicylazosulfapyridine (azulfidine) in the treatment of ulcerative colitis. Sth. med.J. (Bghm, Ala.), 61, 354-358.

Devadatta, S., Gangadharam, P. R. J., Andrews, R. H., Fox, W., Ramakrishnan, C. V., Selkon, J. B., and Velu, S. (1960). Peripheral neuritis due to isoniazid. Bull. Wld Hlth Org., 23, 587-598.

Dick, A. P., Grayson, M. J., Carpenter, R. G., and Petrie, A. (1964). Controlled trial of sulphasalazine in the treatment of ulcerative colitis. Gut, 5, 437-442.

Dixon, W. J. (1967). BMD Biomedical Computer Programs, 2nd ed. Health Sciences Computing Facility, University of California, Berkeley, California.

Evans, D. A. P. (1969). An improved and simplified method of detecting the acetylator phenotype. J. med. Genet., 6, 405-407.

Evans, D. A. P., Davison, K., and Pratt, R. T. C. (1965). The influence of acetylator phenotype on the effects of treating depression with phenelzine. Clin. Pharmacol. Ther., 6, 430-435.

Hansson, K.-A., and Sandberg, M. (1972). Determination of sulfapyridine and its metabolites in biological materials after administration of salicylazosulfapyridine. To be published.

Hawking, F., and Lawrence, J. S. (1950). The Sulphonamides. Lewis, London.

Lagercrantz, R. (1949). Ulcerative colitis in children. Acta paediat. (Uppsala), Suppl., 75, 89-151.

Lennard-Jones, J. E., Longmore, A. J., and Jones, F. A. (1960). A comparative trial of salazopyrin, prednisone and hydrocortisone retention enemata in the out-patient treatment of left-sided colitis. Proc. roy. Soc. Med., 53, 647-650.

Misiewicz, J. J., Lennard-Jones, J. E., Connell, A. M., Baron, J. H., and Jones, F. A. (1965). Controlled trial of sulphasalazine in maintenance therapy for ulcerative colitis. Lancet, 1, 185-188.

Moertel, C. G., and Bargen, J. A. (1959). A critical analysis of the use of salicylazosulfapyridine in chronic ulcerative colitis. Ann. intern. Med., 51, 879-889.

Morrison, L. M. (1952). Results of treatment of ulcerative colitis with salicylazosulfapyridine. Gastroenterology, 21, 133-138.

Sandberg, M., and Hansson, K.-A. (1972). Determination of salicylazosulfapyridine in biological materials. To be published.

Schröder, H., and Campbell, D. E. S. (1972). Absorption, metabolism and excretion of salicyl-azo-sulfapyridine in man. To be published.

Schröder, H., and Evans, D. A. P. (1972). The polymorphic acetylation of sulphapyridine in man. J. med. Genet., in press.

Svartz, N. (1942). Salazopyrin, a new sulfanilamide preparation. Acta med. scand., 110, 577-598.

Svartz, N., Kallner, S., and Helander, S. (1945). Sönderdelas salazopyrin snabbt i organismen? Nord. Med., 25, 211-212.

Truelove, S. C., Watkinson, G., and Draper, G. (1962). Comparison of corticosteroid and sulphasalazine therapy in ulcerative colitis. Brit. med. J., 2, 1708-1711.

Watkinson, G. (1961). Medical management of ulcerative colitis. Brit. med. J., 1, 147-151. 